\title{
DESIGNING AND VALIDATING A TOOL TO ASSESS RISKS AFFECTED HOSPITALIZED PATIENTS IN PORT SAID CITY
}

\author{
Faten Ahmed Mohammed ${ }^{1}$;prof. SaharHamdy El-Said ${ }^{2} \&$ \\ prof. Sanaa Ibrahim Abdel-Azeem ${ }^{3}$; \& Dr. Marwa MohammedAbdel-Aleem ${ }^{4}$ \\ ${ }^{1}$ M.Sc., ${ }^{2,3}$ Professor, ${ }^{4}$ Lecturer Nursing AdministrationDepartment, Faculty of Nursing, \\ ${ }^{1,3,4}$ PortSaid University \& ${ }^{2}$ El-Zagazig University.
}

\begin{abstract}
Background: Today, maintaining quality while eliminating risk is a major challenge facing everyone in the healthcare delivery system. Also, the Patients, healthcare system expect the best care possible, and as well as administrators of healthcare organizations expect healthcare providers to deliver this best care in the most efficient manner. Design: A methodological research design was used to design and validating a tool to assess risks affected hospitalized patient in Port Said city. Setting: The study was conducted in Port Said General Hospital and El-Zohour Hospital. Subject: A sample of 35 experts (faculty and non-faculty members) in nursing and medical field was recruited (jury group). Opinionnaire validating sheet was used for data collection. Results: The highest percentage of the jury group members agreed upon all items, with no statistically significant differences between the two jury groups. The highly reliability coefficient was for the general work condition domain 0.969, while the lowest was for fire measures domain 0.453. Conclusion: The results demonstrated that the majority of two jury group agreed upon the general form (face validity), content of the environmental risk factors tool. Recommendations: Further studies are needed for testing the applicability of the tool. Generalize the designed tool to be used in other hospitals in the country.
\end{abstract}

Keywords: Designing, Validating, Tool, Risk, Patients. 


\section{INTRODUCTION}

Assessment tools are the instruments and techniques used to collect and interpret evidence of competence (Polit, Beck \& Hungler, 2010). Instrument is the activity or specific questions used to evaluate competence by the assessment approach chosen. An assessment instrument may be supported by a profile of acceptable performance and the decision-making rules or guidelines to be used by assessors (Polit, et al, 2010). Procedures: Is the information or instructions given to the candidate and the assessor about how the assessment is to be performed and reported (Khatab, 2013).

Principles of assessment, Validity is the absence of bias in data measurement. It is the ability to accurately evaluate and represent the construct of interest of a test or measurement tool. It emphases on what the test or measurement plan measures and how well it does so. Validity and reliability are interconnected concepts. This can be evaluated by the fact that a measurement cannot be valid unless it is reliable. Therefore, reliability or consistency is a hallmark of validity (Department of Education and Training, 2008). The most common method of validity is referred to as face, content, criterion, and construct. Face validity refers to whether the instrument looks like as though it is measuring the target construct (Polit, et al, 2010).Face validity is not considered a strong demonstration that items of a test are drowning from the domain being measured (Fitzpatrick \& Kazer, 2011). Additionally, Khatab, (2013) mentioned that face validity is a superficial conclusion about the match between a tests appearance and its intended use by asking a panel of experts to judge whether the test appears to be based on appropriate content. It is not sufficient evidence of content representativeness.

Content validity is concerned with the adequacy of coverage of the content area being measured. Content validity is a subjective estimate of measurement reliant on judgment rather than statistical analysis (Fitzpatrick \& Kazer ,2011). Polit et al. (2010) mentioned that construct validity examines the fitness among the conceptual and operational definitions of variables and determines if the instrument really measures the theoretical construct that it's purpose to measure. Criterion related validity refers to the correlation between the measure and the performance on an outside criterion or measure (Polit\&Beck., 2012). Criterion validity is the degree to which an instrument might be used to measure an individual's present or future depending on a concept through comparison of responses to an established standard (Fitzpatrick \& Kazer, 2011). 
Polit et al. (2010) mentioned another perspective; there are two aspects of validity in research: internal and external validity. Internal validity is concerned with the validity of the inferences that, given that an empirical relationship exists, it is the independent variable rather than something else that caused the outcome. External validity is concerned with the validity of the inferences about observed relationships will hold over variations in persons, setting, time, or measures of the outcomes.

Polit et al. (2010) defined that the reliability refers to the degree of consistency and accuracy of the assessment outcomes. That is, the extent to which the assessment will provide comparable outcomes for candidates with the same competence at various times or places, irrespective of the assessor conducting the assessment (Fitzpatrick \& Kazer, 2011).Internal consistency is scales and tests that involve summing item scores are typically evaluated for their internal consistency. Scales planned to measure an attribute ideally are consists of items that measure that attribute and nothing else.

Flexibility refers to the opportunity for a candidate to negotiate certain aspects of their assessment (for instance, timing) with their assessor. All candidates have to be fully informed about the aim of assessment, the assessment criteria, approaches and tools used, and the context and timing of the assessment. (Department of Education and Training, 2008). Fair assessment does not disadvantage certain candidates or groups of candidates. This may denote that assessment approaches are adjusted for certain candidates (for example people with disabilities or cultural differences) to confirm that the approach does not disadvantage them owing to their situation. An assessment should not place unnecessary demands on candidates that may prevent a candidate from demonstrating competence (for example, an assessment should not demand a higher level of English language or literacy than that which is needed to conduct to the workplace standard outlined in the competencies being evaluated (Polit, et al, 2010).

Espin, Lingard, Baker, \& Regehr, (2016) mentioned that enhancing patient safety through participation in National Patient Safety Goals, organizational safety strategies and other patient safety initiatives, enhancing environmental safety for patients, visitors and staff through participation in environment of care-related activities ,utilizing risk management strategies to identify and minimize the frequency and severity of near misses, incidents and claims ,managing adverse events and injuries to minimize financial loss, evaluating systems that can contribute to patient care, error or injury 
,educating stakeholders on emerging and known risk exposures and risk reduction initiatives , achieving requirements promulgated by accrediting organizations ,complying with state-specific scope of practice, applicable laws, regulations and standards. on the other hand, for a healthy hospital environment for patient depend on requirements of evidence based design of hospital, floor space for beds, inter bed space, safe water supply, proper sanitation and housekeeping, effective biomedical waste management, adequate hand washing facilities, isolation facilities, and ventilation (Hansen, Landstad, Gundersen, \& Vinberg. 2016).

\section{AIM OF STUDY:}

The aim of this study is to design and validate a tool to assess risks affecting hospitalized patients in Port Said City through:

1. Designing a tool for assessing risk affecting hospitalized patients

3. Testing the Validity of the proposed tool.

4. Designing final form of risk factors tool affecting hospitalized patients tool.

\section{SUBJECTS AND METHODS:}

\section{(I) TECHNICAL DESIGN:}

\section{Research design:-}

A methodological design was used to design and validate a tool to assess risks affecting hospitalized patients in Port Said City including face and content validity, reliability.

\section{Setting:}

This study was conducted at all inpatient units at Port Said General Hospital, and ElZohour Central Hospital, which affiliated to the Ministry of Health in Port Said City

\section{Subjects}

Two groups of subjects were included in the study; 


\section{Jury group:}

The jury group was recruited for testing the face and content validity of the preliminary tool. This group consists of 35 members from twelve faculty members and twenty three of non-faculty members.

1- Faculty members $(n=12)$ consist of five professors and assistant professors from teaching staff from nursing administration and medical and surgical departments at the Faculty of Nursing in Port Said University; seven professors from Faculty of Nursing, Alexandria University.

2- Non-faculty members: with total number were 23 who were working in different sectors in hospitals; 11 managers (6 physicians and 5nurses), 3 engineers working in the maintenance department, 2 physicians working in the infection control department and 7 experts in quality recruited from different hospitals. (Al Defaa El Gay Hospital in Cairo city -Ataa Hospital in port said city)

\section{TOOLS FOR DATA COLLECTION:}

TOOL (I): Questionnaire sheet was developed by the researcher based on relevant literature review (CDC, 2008;OSHA, 2009; Burden \& Quinn, 2010; Abo-El Hassan, 2011; JCAHO, 2012; George, 2015; The Association for Professional in Infection Control and Epidemiology (APIC), 2015). This tool aims at testing both face and content validity of the preliminary assessment, environmental risk factors tool from experts' point of view.

\section{Part I:}

This part intended to collect data related to personal and job characteristics of the jury including : Age, gender, educational level and years of experience.

\section{Part II:}

This part was aimed at testing the face validity of a preliminary tool through eliciting the jury groups' opinions regarding the general form of preliminary tool. The jury groups were responding to eight statements regarding the general form of preliminary tool as agrees or disagrees; in addition to commenting Colum. 


\section{Part III:}

Aimed at determining content validity through jury group opinions upon the preliminary tool items. It entails a list of 278 items concerning : Risk affecting hospitalized patient, grouped under 21 dimensions follows; human resources (six items), education and training (20 items), housekeeping (nine items), general work conditions (24 items), ventilation (7 items), lighting and electricity (11 items), food (20 items), water supply (7 items), furniture \& Equipment (13 items), material handling \& storing (12 items), maintenance (7 items), protect patient from falling (17 items), protect patient from bed sores (10 items), disaster and crises (6 items), fire (14 items), waste disposal (16 items), infection control (21 items), basic principles of infection control when dealing with linens and furnishing (seven items), medication errors (22 items), general safety rules (18 items), and risk management (11 items).

\section{The scoring system:}

The responses were either " agree" or "disagree" which were respectively scored "2" and "1" with a space left for any comments, corrections, advices, suggestions and overall impression. For each dimension of factors, the score of items was summed-up and the total divided by the number of the items, giving a mean score for the piece. These scores were converted into percent score.

\section{Face validity:}

The face validity was tested through the responses of the juries toward the overall questions of the preliminary environmental risk factors tool regarding the general format of the proposed tool: Does the preliminary tool like a tool for environmental risk factors?

\section{Content validity:}

The content validity was tested through eliciting jury's opinions as agree, disagree and their comments regarding (278) sub items of the preliminary environmental risk factors tool.

\section{(II) OPERATIONAL DESIGN:}


The operational design for this study included three stages; preparatory stage, pilot study and fieldwork.

\section{Preparatory stage (lasting ten month)}

This stage started from beginning of August 2015 till end May 2016. During this stage, the preliminary environmental risk factors tool was designed based on a literature review .

\section{Pilot study (lasting four months)}

A pilot study was carried out after designing the environmental risk factors tool. It was carried out before starting field work and data collection. The aim of the pilot study was examining the clarity of language and feasibility of the environmental risk factors tool and to identify the obstacles and problems that may be encountered while data collection, and determine the applicability of the tool.

The pilot study was conducted on eight physicians, 14 nurses, four housekeepers, and six patients selected randomly from inpatient units at Port Said General Hospital and El-Zohour Hospital. In the light of the findings of the pilot study, the tool was modified and put in the final forms.

\section{Fieldwork Stage (lasting ten months):}

The actual field work begins after preparation and piloting of the preliminary environmental risk factors tool. It was extended through the time period from the beginning of May 2016 until the end of February 2017. The main objective of the fieldwork was testing validity, reliability of the preliminary environmental risk factors tool and implementing the final version of the tools through the following three phases: Phase I (Validity), phase II (reliability), and phase III (developed tools).

\section{Phase (I): (Validity):}

The preliminary tool form and the opinionnaire sheet were distributed to the jury in their work settings to examine face and content validity of the tool. The jury received a full explanation about the study purpose and informed jury group members that their responses would be treated with the strict test confidence. The time needed to complete 
each opinionnaire sheet 60 minutes. This stage took about 4 months in order to get the opinionnaire sheets filled by all jury group members.

\section{Phase (II):}

After completion of the sheets reviewing and discussing their comments, the opinionnaire sheets were analyzed and the preliminary statistical analysis was done to obtain the valid items on the preliminary assessment environmental risk factors tool. Modifications and redesigning of the preliminary tool was done, then the preliminary tool redistributed again for final agreement.

\section{Phase (III):}

This step aimed at confirming the tool validity by conduct constructs validity using factor analysis approach. Items analysis was used to assess the internal consistency of the instrument which reflected in the value of Cronbach's alpha coefficient.

\section{(III) ADMINISTRATIVE DESIGN}

Before starting any step in the study, an official letter was obtained from the Dean of the Faculty of Nursing, Port Said University, to the Director of both Hospitals, for permission and cooperation to conduct the study.

\section{Ethical Considerations:}

The study was approved by the Ethics Committee at the Faculty of Nursing; Port Said University. The verbal explanation of the nature, purpose, and benefits of the study was performed by the researcher to the subjects included in the study sample. Oral consent was taken from subjects and reassured them about confidentiality and anonymity of the study. They were informed about their right to refuse or withdraw from the study at any time without giving a reason.

\section{(IV) STATISTICAL DESIGN:}

Upon completion of data collection, data were revised, coded and entered using the PC. Data entry and statistical analysis were fulfilled using the Statistical Package for Social Sciences (SPSS) package version 20.0. (Armonk, NY: IBM Corp). Data were presented using descriptive statistics in the form of frequencies, percentages, mean and standard 
deviations for quantitative variables. And the X2 Test square test was used for comparisons between qualitative variables, Cronbach's alpha was used for consistency reliability of the tool.

- Statistical significance was considered at $p$-value $<0.05$.

\section{RESULTS:}

Table (1): shows that all non-faculty member jury group (100\%) agreed upon, all items on the preliminary tool. While all faculty member jury group (100\%) agreed upon the items related to the tool looks like environmental risk factor assessment, the tool can be used as a guide to health members working in a hospital, and the tool format is included a representative item under every dimension. With no statistically significant differences between the two jury groups.

Table (2): illustrates that all and highest percentage (91.7\%) of the faculty member and non-faculty member jury group members agreed upon all items of content validity. With no statistically significant differences between the two jury groups.

Factor analysis of construct validity for the preliminary tool dimensions illustrated in table (3): reveals that the highest mean score was related to infection control, Waste Disposal, risk management, and disaster and crises, $(2.0 \pm 0.02,2.0 \pm 0.01,2.0 \pm 0.0, \&$ $\mathbf{2 . 0} \pm \mathbf{0 . 0}$ respectively $)$, while the lowest mean score was related to ventilation $(\mathbf{1 . 9 4} \pm$ 0.18).

Testing the Internal consistency of the environmental risk factors tool illustrated in figure 1. It's clear that the highly reliability coefficient was for the general work condition domain (0.969), while the lowest was for fire measures domain $(\mathbf{0 . 4 5 3})$.

Table (4): present the stability of the preliminary tool, test-retest reliability reveals significance statistical relationship correlation $(\mathbf{r}=\mathbf{0 . 9 2 4})$ at level $(\mathbf{0 . 0 1})$. These reflect that the test re-test are strongly correlated. In addition, the Wilcoxon test shows that $(\mathbf{z}=\mathbf{1 . 6 8 8})$, this mean that there is no significance statistical difference between the mean of two measurements. Therefore, the test -re-test reliability indicates that the tool is highly stabilizes. 
Table (5): presents the results of the internal consistency reliability analysis of the preliminary tool. It indicates that generally very good Cronbach' alpha coefficients of reliability that factor loading ranged between 0.700 and 0.899 .

Table (1): Agreement of jury group upon face validity of proposed tool $(\mathrm{N}=35)$

\begin{tabular}{|c|c|c|c|c|c|c|}
\hline & \multirow{3}{*}{ Face validity } & \multicolumn{4}{|c|}{ "Jury group members } & \multirow{3}{*}{$\begin{array}{c}\mathbf{P} \\
\text { Value }\end{array}$} \\
\hline & & \multicolumn{2}{|c|}{$\begin{array}{l}\text { Faculty members } \\
\qquad(\mathrm{n}=12)\end{array}$} & \multicolumn{2}{|c|}{$\begin{array}{c}\text { Non faculty } \\
\text { members } \\
(\mathbf{n}=\mathbf{2 3})\end{array}$} & \\
\hline & & Agree & $\%$ & Agree & $\%$ & \\
\hline 1 & $\begin{array}{l}\text { The tool looks like environmental } \\
\text { risk factor assessment }\end{array}$ & 12 & 100.0 & 23 & 100.0 & 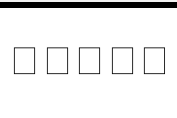 \\
\hline 2 & $\begin{array}{l}\text { The demographic information is } \\
\text { enough }\end{array}$ & 10 & 83.3 & 23 & 100.0 & प्र०० \\
\hline 3 & $\begin{array}{l}\text { The tool is considered an important } \\
\text { practice to assess the environmental } \\
\text { risk factor }\end{array}$ & 11 & 91.7 & 23 & 100.0 & प्र०० \\
\hline 4 & $\begin{array}{l}\text { The tool items are relevant to its } \\
\text { title }\end{array}$ & 11 & 91.7 & 23 & 100.0 & प्र०० \\
\hline 5 & $\begin{array}{l}\text { The tool can be used as a guide to } \\
\text { health members working in a } \\
\text { hospital }\end{array}$ & 12 & 100.0 & 23 & 100.0 & 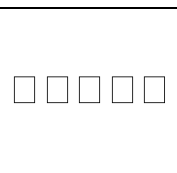 \\
\hline 6 & $\begin{array}{l}\text { The tool format is included a } \\
\text { representative items under every } \\
\text { dimension. }\end{array}$ & 12 & 100.0 & 23 & 100.0 & 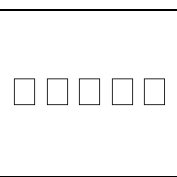 \\
\hline 7 & $\begin{array}{l}\text { The numbers of items under every } \\
\text { title of the tool are suitable }\end{array}$ & 10 & 83.3 & 20 & 87.0 & 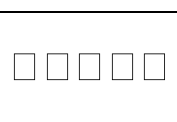 \\
\hline 8 & $\begin{array}{l}\text { The tool items statements were } \\
\text { considered clear, specific and } \\
\text { understandable words }\end{array}$ & 10 & 83.3 & 23 & 100.0 & $\square \square \square \square \square$ \\
\hline
\end{tabular}

*: Statistically significant at $\mathrm{p} \leq 0.05$ 
Table (2): Agreement of jury group upon content validity of proposed tool (N=35)

\begin{tabular}{|c|c|c|c|c|c|c|}
\hline & \multirow{3}{*}{ Content validity } & \multicolumn{4}{|c|}{ Jury group members } & \multirow{3}{*}{$\begin{array}{c}\mathbf{P} \\
\text { Value }\end{array}$} \\
\hline & & \multicolumn{2}{|c|}{$\begin{array}{l}\text { Faculty members } \\
\qquad(\mathrm{n}=12)\end{array}$} & \multicolumn{2}{|c|}{$\begin{array}{c}\text { Non faculty } \\
\text { members } \\
(\mathbf{n}=23)\end{array}$} & \\
\hline & & Agree & $\%$ & Agree & $\%$ & \\
\hline 1 & Human resources & 12 & 100.0 & 20 & 87.0 & $\square \square \square \square \square$ \\
\hline 2 & Education and training & 11 & 91.7 & 10 & 83.3 & $\square \square \square \square \square$ \\
\hline 3 & Housekeeping & 12 & 100.0 & 23 & 100.0 & $\square \square \square \square \square$ \\
\hline 4 & General work conditions & 11 & 91.7 & 20 & 87.0 & $\square \square \square \square \square$ \\
\hline 5 & Ventilations: & 11 & 91.7 & 19 & 86.0 & $\square \square \square \square \square$ \\
\hline 6 & Lighting and electricity & 12 & 100.0 & 22 & 99.0 & $\begin{array}{l}\square \square \square \square \\
\end{array}$ \\
\hline 7 & a-Kitchen design & 12 & 100.0 & 20 & 87.0 & $\square \square \square \square \square$ \\
\hline 8 & B-Food cooking & 10 & 83.3 & 20 & 87.0 & $\begin{array}{l}\square \square \square \square \\
\end{array}$ \\
\hline 9 & Water & 10 & 83.3 & 23 & 100.0 & $\square \square \square \square \square$ \\
\hline 10 & Furniture and equipment & 12 & 100.0 & 22 & 99.0 & $\square \square \square \square \square$ \\
\hline 11 & Material handling and storing & 12 & 100.0 & 20 & 87.0 & $\square \square \square \square \square$ \\
\hline 12 & Maintenance & 12 & 100.0 & 20 & 87.0 & $\square \square \square \square \square$ \\
\hline 13 & Protect patient's from falling & 11 & 91.7 & 23 & 100.0 & $\square \square \square \square \square$ \\
\hline 14 & Protect patient from bed sores & 12 & 100.0 & 23 & 100.0 & $\square \square \square \square \square$ \\
\hline 15 & Disaster and crises & 12 & 100.0 & 23 & 100.0 & $\square \square \square \square \square$ \\
\hline 16 & Fire & 12 & 100.0 & 20 & 87.0 & $\square \square \square \square \square$ \\
\hline 17 & Waste disposal & 10 & 83.3 & 20 & 87.0 & $\square \square \square \square \square$ \\
\hline 18 & Infection control & 10 & 83.3 & 20 & 87.0 & $\square \square \square \square \square$ \\
\hline 19 & $\begin{array}{l}\text { Basic principles of infection } \\
\text { control }\end{array}$ & 12 & 100.0 & 20 & 87.0 & $\square \square \square \square \square$ \\
\hline 20 & Medication error & 12 & 100.0 & 23 & 100.0 & $\square \square \square \square \square$ \\
\hline 21 & General safety rules & 12 & 100.0 & 23 & 100.0 & $\square \square \square \square \square$ \\
\hline 22 & Risk management & 12 & 100.0 & 23 & 100.0 & $\square \square \square \square \square$ \\
\hline
\end{tabular}


Table (3): Factor analysis of construct validity for the preliminary tool dimensions

\begin{tabular}{|c|l|c|c|c|}
\hline $\begin{array}{c}\text { Factor } \\
\text { No. }\end{array}$ & \multicolumn{1}{|c|}{ Factor name } & $\begin{array}{c}\text { No. of } \\
\text { items }\end{array}$ & Mean \pm SD & Variance \\
\hline $\mathbf{1}$ & Human resources & $\mathbf{6}$ & $1.99 \pm 0.04$ & 1.97 \\
\hline $\mathbf{2}$ & Education and training & $\mathbf{2 0}$ & $1.99 \pm 0.06$ & 3.03 \\
\hline $\mathbf{3}$ & Housekeeping & $\mathbf{9}$ & $1.99 \pm 0.04$ & 2.08 \\
\hline $\mathbf{4}$ & General work conditions & $\mathbf{2 4}$ & $1.97 \pm 0.10$ & 5.00 \\
\hline $\mathbf{5}$ & Ventilations & $\mathbf{7}$ & $1.94 \pm 0.18$ & 9.34 \\
\hline $\mathbf{6}$ & Lighting and electricity & $\mathbf{1 1}$ & $1.97 \pm 0.12$ & 6.02 \\
\hline $\mathbf{7}$ & A-Kitchen design & $\mathbf{1 2}$ & $1.99 \pm 0.06$ & 2.96 \\
\hline $\mathbf{8}$ & B-Food cooking & $\mathbf{8}$ & $1.99 \pm 0.03$ & 1.48 \\
\hline $\mathbf{9}$ & Water & $\mathbf{7}$ & $1.98 \pm 0.07$ & 3.56 \\
\hline $\mathbf{1 0}$ & Furniture and equipment & $\mathbf{1 3}$ & $1.96 \pm 0.10$ & 5.15 \\
\hline $\mathbf{1 1}$ & Material handling and storing & $\mathbf{1 2}$ & $1.99 \pm 0.04$ & 2.22 \\
\hline $\mathbf{1 2}$ & Maintenance & $\mathbf{7}$ & $1.99 \pm 0.05$ & 2.68 \\
\hline $\mathbf{1 3}$ & Protect patient's from falling & $\mathbf{1 7}$ & $1.99 \pm 0.05$ & 2.50 \\
\hline $\mathbf{1 4}$ & Protect patient from bed sores & $\mathbf{1 0}$ & $1.99 \pm 0.06$ & 2.77 \\
\hline $\mathbf{1 5}$ & Disaster and crises & $\mathbf{6}$ & $2.0 \pm 0.0$ & 0.00 \\
\hline $\mathbf{1 6}$ & Fire & $\mathbf{1 4}$ & $1.99 \pm 0.06$ & 3.08 \\
\hline $\mathbf{1 7}$ & Waste Disposal & $\mathbf{1 6}$ & $2.0 \pm 0.01$ & 0.74 \\
\hline $\mathbf{1 8}$ & Infection control & $\mathbf{2 1}$ & $2.0 \pm 0.02$ & 0.81 \\
\hline $\mathbf{1 9}$ & Basic principles of infection & $\mathbf{1 8}$ & $1.99 \pm 0.03$ & 1.48 \\
\hline $\mathbf{2 0}$ & control when dealing with linens & $\mathbf{7}$ & $1.98 \pm 0.08$ & 3.82 \\
\hline $\mathbf{2 1}$ & Gedication error & $\mathbf{1 1}$ & $2.0 \pm 0.0$ & 0.00 \\
\hline $\mathbf{2 2}$ & Risk management & & $1.97 \pm 0.09$ & 4.61 \\
\hline
\end{tabular}

Mean and standard deviations for quantitative variables 
Figure (1): Testing the Internal consistency of the risks affected hospitalized patient

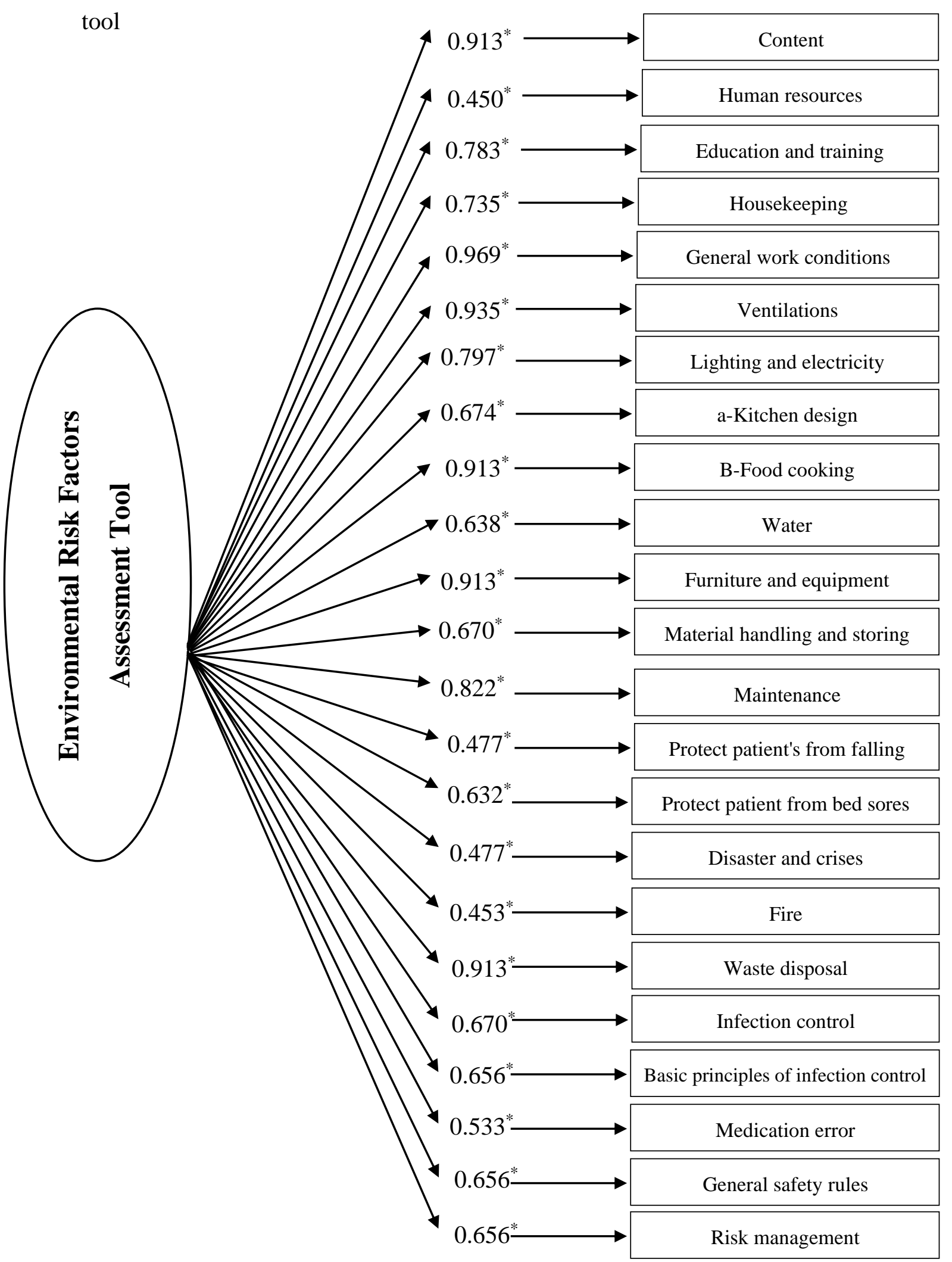


Table (4): Mean standard deviation, correlation and $\mathrm{Z}$ value of Wilcoxon to test the stability of the tool

\begin{tabular}{|l|c|c|c||}
\hline Applied & Mean \pm SD & Correlation & $\mathbf{Z}$ \\
\hline Test & $98.28 \pm 4.09$ & 0.924 & 1.688 \\
\hline Re-test & $97.84 \pm 3.73$ & & \\
\hline
\end{tabular}

Table (5): Testing the internal consistency of the tool sub scale

\begin{tabular}{||l|l|l|l|l||}
\hline $\begin{array}{l}\text { Factor } \\
\text { No. }\end{array}$ & Factor name & $\begin{array}{l}\text { No. of } \\
\text { Jury }\end{array}$ & $\begin{array}{l}\text { No. of } \\
\text { items }\end{array}$ & $\begin{array}{l}\text { Factor } \\
\text { loading }\end{array}$ \\
\hline $\mathbf{1}$ & Human resources & 35 & $\mathbf{6}$ & 0.830 \\
\hline $\mathbf{2}$ & Education and training & 35 & $\mathbf{2 0}$ & 0.847 \\
\hline $\mathbf{3}$ & Housekeeping & 35 & $\mathbf{9}$ & 0.734 \\
\hline $\mathbf{4}$ & General work conditions & 35 & $\mathbf{2 4}$ & 0.893 \\
\hline $\mathbf{5}$ & Ventilations & 35 & $\mathbf{7}$ & 0.873 \\
\hline $\mathbf{6}$ & Lighting and electricity & 35 & $\mathbf{1 1}$ & 0.882 \\
\hline $\mathbf{7}$ & A-Kitchen design & 35 & $\mathbf{1 2}$ & 0.720 \\
\hline $\mathbf{8}$ & B-Food cooking & 35 & $\mathbf{8}$ & 0.830 \\
\hline $\mathbf{9}$ & Water & 35 & $\mathbf{7}$ & 0.899 \\
\hline $\mathbf{1 0}$ & Furniture and equipment & 35 & $\mathbf{1 3}$ & 0.800 \\
\hline $\mathbf{1 1}$ & Material handling and storing & 35 & $\mathbf{1 2}$ & 0.853 \\
\hline $\mathbf{1 2}$ & Maintenance & 35 & $\mathbf{7}$ & 0.764 \\
\hline $\mathbf{1 3}$ & Protect patient's from falling & 35 & $\mathbf{1 7}$ & 0.850 \\
\hline $\mathbf{1 4}$ & Protect patient from bed sores & 35 & $\mathbf{1 0}$ & 0.893 \\
\hline $\mathbf{1 5}$ & Disaster and crises & 35 & $\mathbf{6}$ & 0.750 \\
\hline $\mathbf{1 6}$ & Fire & 35 & $\mathbf{1 4}$ & 0.828 \\
\hline $\mathbf{1 7}$ & Waste Disposal & 35 & $\mathbf{1 6}$ & 0.700 \\
\hline $\mathbf{1 8}$ & Infection control & 35 & $\mathbf{2 1}$ & 0.825 \\
\hline & Basic principles of infection & & & \\
$\mathbf{1 9}$ & $\begin{array}{l}\text { control when dealing with linens } \\
\text { and furnishings }\end{array}$ & 35 & $\mathbf{7}$ & 0.799 \\
\hline $\mathbf{2 0}$ & Medication error & 35 & $\mathbf{2 2}$ & 0.863 \\
\hline $\mathbf{2 1}$ & General Safety Rules & 35 & $\mathbf{1 8}$ & 0.834 \\
\hline $\mathbf{2 2}$ & Risk management & 35 & $\mathbf{1 1}$ & 0.700 \\
\hline
\end{tabular}




\section{DISCUSSION:}

The main responsibility for the working environment devolves on the organization, all measures needed must take to prevent the exposure of the patient to the risk of the environment, one of the basic principles of the employer's preventive activity must be for everything dangerous to be altered or replaced to eliminate the risk, this also implies that, if the risk cannot be fully eliminated, the employer must instead take steps to reduce it (Carayon and Alvarado., 2007).

The aim of the present study was designed and validate a tool to assess risks affecting hospitalized patients in Port Said City. The findings of the current study was classified into seven main parts which are; personal and job characteristics of jury group, face and content validity of the tool to assess risk by jury group, $\mathrm{T}$ testing the reliability of the preliminary tool through Cronbach's alpha coefficient, construct validity of the tool through factor analysis, personal and job characteristics of the health team and patient, health team and patients' opinions about the importance of environmental risk factor tool.

The findings of the present study show that the majority of jury members agreed upon, all items regarding the general form of the preliminary assessment environmental risk factors tool (face validity). While all of non faculty members are agreeing upon all items compared to faculty members. This may be due to the jury group members have the knowledge, awareness \& ability to evaluate and analyze what the environmental risk factors that affects on hospitalized patients. It was represented all agreements of juries group members regarding the preliminary tool looks like a tool for assessing environmental risk factors. Therefore, the tool has acceptable face validity and truly reflects the concepts it is supposed to measure. This finding was in agreement with a study conducted in Ain Shams University by Abo El-Hassan (2011) who designing and validating a tool assess environmental risk factors affecting hospitalized patients in ICUs and found that all of jury group agreed on all topics and subtopics of the environmental risk factor tool. In this respect with Fitzpatrick and Kazer, (2011), who stated that, face validity is a way of saying the instrument looks as if it measures what it says it measures. Again the study conducted in California Faculty by Hessler and Humphrys, (2008), who tested the face validity of tool for evaluating clinical nurse instructor performance by the students and found that all jury members agreed upon the general form of the preliminary tool. 
Content validity is the degree to which the items of a tool adequately represent the content of the universe. This is the most important type of validity because it ensures a match between the research target and data collecting tool (Cohen \&Morrison , 2013). The evidence supporting the content validity of the environmental risk tool was based firstly on literature review, and secondly, on the judgment of thirty five experts.

The findings of the current study reveal that the jury groups agreement upon the content validity of the environmental risk factor tool, while the faculty members have highest mean score of agreement upon the content validity of the tool than non faculty members with no statistically significant differences between both groups of the jury. The explanation for these results the all items of the tool covered environmental risk factors and represent the domains of content addressed by the instrument. This finding consisted with Abo-El Hassan (2011), who found that the majority of jury group agreed about items of environmental risk tools, and there is no statistical difference between two groups

\section{Testing the Reliability of the Tool:}

The reliability of the preliminary tool was ascertained by test-retest reliability method, in the present study, test-retest reliability reveals statistically significant strong correlations; the items had high correlation coefficients(r), which $(0.924)$ this provides further strength to the designed tool in the present study. In this respect with Polit et al., (2010) who stated that for most purposes, the reliability coefficient higher than 0.70 are satisfactory, but coefficients in the range of 0.85 to 0.95 are more preferable reliability refers to the degree of consistency and accuracy of the assessment outcomes.

The reliability of the proposed tool was also ascertained by testing the internal consistency of the validated environmental risk tool which include - sub items grouped under-dimensions using Cronbach's alpha coefficient. Therefore, Mc Donald (2009) identified that if the tool includes a lot of items, Cronbach's alpha coefficient tends to be the most frequently used for measuring the internal consistency.

\section{Testing Construct Validity of the Tool:}

In relation of constructive validity using factor analysis, which clearly demonstrates that a number of distinct and meaningful dimensions measured by these items. This might be due to construct validity examines the fitness between the conceptual definitions and 
operational At the same line, Abo-El Hassan (2011) have conducted factor analysis to check the validity of the evaluation tool to determine the major elements of clinical teaching behavior and identified the underlying teaching dimensions or factors on which clinical instructor vary. In this respect with Polit, et al.(2010) emphasized that, validating an instrument in terms of construct validity is a challenging task\& construct validation can be approached in several ways, but it always logical analysis and tests predicted by theoretical consideration.

\section{CONCLUSION:}

Based on the study findings, it can be concluded that: The majority of jury group agreed upon the general form (face validity), dimensions and its sub items of the hospital risk factors tool.

\section{RECOMMENDATIONS:}

Generalize the designed tool to be used in other hospitals in the country.

\section{REFERENCES:}

Abo-El Hassan, N. (2011): Designing and validating a tool to assess environmental risk factors affecting hospitalized patients. (Unpublished doctorate thesis, faculty of nursing, Ain Shams University, Egypt).

Association for Professional in Infection Control and Epidemiology (APIC). (2015): $2^{\text {nd }}$ edition text of infection control and epidemiology, aseptic technique- 20-2, respiratory care 63.

Burden, Quinn, O’Brien and Dawes, (2010): Quality assurance and risk reduction guidelines. Acta Cytol. ...... Quinn MA. Adenocarcinoma of the cervix - are there arguments for a different. Available at www.cervicalcheck.ie/QAfinal- webversion.

Carayon, P., \& Alvarado, C. J. (2007): Workload and patient safety among critical care nurses. Critical care nursing clinics of North America, 19(2), 121-129.

Centers for Disease Control and Prevention. (2008): Self-reported falls and fall-related injuries among persons aged > or $=65$ years--United States, 2006. MMWR: Morbidity and mortality weekly report, 57(9), 225-229.

Cohen, L., Manion, L., \& Morrison, K. (2013): Research Methods in Education. Routledge 
Department of Education and Training (DET) (2008):Guidelines for assessing competence in VET. DET, East Perth, Western Australia.

Espin, S., Lingard, L., Baker, G. R., \& Regehr, G. (2016): Persistence of unsafe practice in everyday work: an exploration of organizational and psychological factors constraining safety in the operating room. BMJ Quality \& Safety, 15(3), 165170.

Fitzpatrick, J. J. (Ed.) \& Kazer, M.W. [Wallace], (Assoc. Ed). (2011): Encyclopedia of Nursing Research. 3rd Edition. New York: Springer Publishing Company, ISBN (9780826107503), Publication date, August 24, 2011.

George, J., Farina, (2015): Environment of Care; Hand Book. Second Edition.Joint Commission Resources. USA. New York.

Hansen, E., Landstad, B. J., Gundersen, K. T., \& Vinberg, S. (2016):LeaderBased Workplace Health Interventions-A Before-After Study in Norwegian and Swedish Small-Scale Enterprises. International Journal of Disability Management, 11.

Hessler, K., \& Humphreys, J. (2008): Student evaluations: Advice for novice faculty. Journal of Nursing Education, 47(4), 187-189.

Joint Commission on Accreditation of Healthcare Organizations (JCAHO) (2012): The Safety Checklist Program: Creating a Culture of Safety in Intensive Care Units. Volume 28, Number6

Khatab, A. (2013): Reliability and Validity of Measures. International Journal of Consumer Studies, 31 (6), 648- 658.

McDonald, K.M. (2009): Making health care safer: a critical analysis of patient safety practices Evidence report/technology assessment, No 43. New York, MD: Agency for Healthcare Research and Quality; Fatigue, sleepiness, and medical errors. Chapter 40. Available at www.ahrq.gov/clinic/ptsafety/chap40.htm.

OSHA Inspection Checklist (2009): Presented by OSHA council. www.abc.org/. p. 309.

Polit, D. F., \& Beck, C. t, \& Hungler, BP, (2010): Essentials of Nursing Research: Methods, appraisal and Ufilizafion.

Polit, D. F., \& Beck, C. T. (2012). Nursing research: Principles and methods. Lippincott Williams \& Wilkins. 


\section{تصميم واختبار مصداقية أداة لتقيم المخاطر التي تؤثر علي المـرضسي بمستشفيات

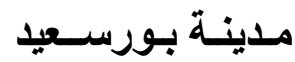

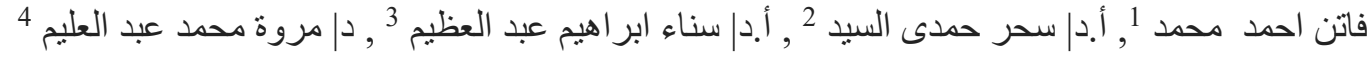

$$
\begin{aligned}
& 1 \text { ماجستير ، 3،2 أستاذ ، } 4 \text { محاضر بقسم إدارة التمريض ، كلية التمريض ، 4، 3، } 1 \text { جامعة بورسعيد و }{ }^{3} \text { ، جامعة } \\
& \text { الزقازيق. }
\end{aligned}
$$

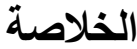

تعدالحفاظ على الجودة مع القضاء على المخاطر هو التحدي الرئيسي الذي يواجه الجميع في نظام تقديم الرعاية الصحية. ومن المتوقع تقديم افضل رعاية ممكنة ، ويتوقع مديرو مؤسسات الرعاية الصحية من مقدمي الر عاية الصحية تقديم هذه الرعاية بأفضل طريقة فعالة.. تهدف هذه الدراسة الى تصميم وقياس مصداقية أداة لتقييم المخاطر التي تؤثر علي المرضى بمستشفيات مدينة بورسعيد ـ تم تصميم در اسة منهجية ـ أجريت الدر اسة في مستشفى بورسعيد العام ومستشفى الزهور. تكونت عينة الاراسة من 35 خبير (أعضاء هيئة التدريس و غير أعضاء هيئة التندريس) في مجال التمريض و الطب (مجمو عة المحلفين) لقياس مدي مصداقية الأداة المصممة ـ تم

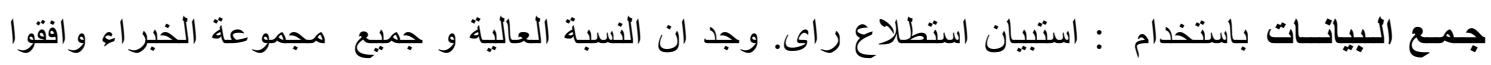
على كل العناصر المكونة للأداة, مع عدم وجود فروق ذات دلالة إحصائية بين مجموعتي الخبراء , بالنية والنسبة

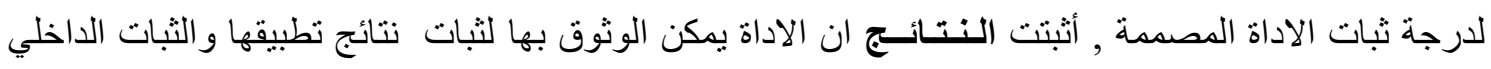
0.969 بينما كان الأقل لمجال مقاييس الحريق (0.453). الخلاصة: بينت النتائج أن أغلبية مجموعتي الخبراء اتفقت على الثكل العام (صلاحية الوجه) ومحتوى أداة عوامل المخاطر البيئية. لذا توصي الدراسة هناك حاجة إلى مزيد من الدراسات لاختبار قابلية تطبيق الأداةمع تعميم الأداة المصممة لتستخدم في مستشفيات أخرى في المحافظه. الكلمات المرشدة : التصـيـم ، مصداقيه، الاداه, المـخـاطر ، الــرضـى 